\title{
Hemipleji ile Başvuran HIV Enfeksiyonu: Üç Toksoplazma Ensefaliti Olgusu
}

\section{HIV Infection Presented with Hemiplagia: Three Cases of Toxoplasma Encephalitis}

\author{
Aslıhan Demirel, Reşat Özaras*, Elif Hakko**, Bilgül Mete*, Mücahit Yemişen*, Ali Mert*, \\ Recep Öztürk*, Fehmi Tabak* \\ Istanbul Bilim Üniversitesi Tıp Fakültesi, Enfeksiyon Hastalıkları ve Klinik Mikrobiyoloji Anabilim Dalı, İstanbul, Türkiye \\ *istanbul Üniversitesi Cerrahpaşa Tıp Fakültesi, Enfeksiyon Hastalıkları ve Klinik Mikrobiyoloji Anabilim Dalı, Istanbul, Türkiye \\ **Anadolu Sağlık Merkezi, Enfeksiyon Hastalıkları Kliniği, Kocaeli, Türkiye
}

\section{Özet}

Toksoplazma ensefaliti, genellikle ilerlemiş immün yetersizliği olan hastalarda, radyolojik olarak çepersel kontrast tutan beyin lezyonlarının varlığında ayırıcı tanıda ilk sıradadır. Bu makalede, toksoplazma ensefaliti ile başvuran HIV enfeksiyonlu olgular sunulmuştur. 28 yaşında erkek hasta ateş ve vücut sol yarısında güçsüzlük yakınmalarıyla kliniğimize başvurdu. Kraniyal MR'da merkezleri nekrotik, kontrast tutan toksoplazmoz ile uyumlu lezyonlar görülmesi üzerine istenen tetkikler sonucunda HIV enfeksiyonu tanısı koyuldu. Toksoplazma tedavisinin 14. gününde lezyonlarda belirgin gerileme olup, klinik bulguları düzeldi. 37 yaşında kadın hasta baş ağrısı, ateş ve sol kol ve bacakta güçsüzlük yakınmalarıyla kliniğimize başvurdu. Kraniyal MR'da izlenen çepersel kontrast tutan, çoklu lezyonların toksoplazmayı düşündürmesi üzerine istenen tetkikler sonucunda HIV enfeksiyonu tanısı koyuldu. Toksoplazma tedavisinin 12. gününde hastanın ateşi ve klinik bulguları geriledi. 12 yı önce HIV pozitifliği saptanan ancak tedaviyi reddeden 29 yaşında erkek hasta, sağ kolda güçsüzlük ve konuşmada güçlük şikayetleri ile kliniğimize başvurdu. Kraniyal MR'da toksoplazma ensefaliti düşündüren lezyonlar saptanması üzerine hastaya başlanan toksoplazma tedavisinin 15. gününde lezyonların boyutlarında regresyon izlendi ve nörolojik bulgular düzeldi. Sonuç olarak; fokal beyin lezyonları saptanan hastalarda, HIV enfeksiyonu ve onun kolaylaştırdığı patolojiler akılda tutulmalıdır. (Haseki Tıp Bülteni 2013; 51: 70-5)

Anahtar Kelimeler: Toksoplazma ensefaliti, HIV, hemipleji

\section{Abstract}

In the presence of contrast-enhanced focal parietal lesions in patients with advanced immunodeficiency, toxoplasma encephalitis is among the main entities in the differential diagnosis. In this study, we report the cases of three patients with HIV infection presented with toxoplasma encephalitis. A 28-year-old male patient was admitted with fever and weakness in the left half of the body. Cranial MRI revealed contrast-enhancing lesions with necrotic centers compatible with toxoplasmosis. Based on further analysis, the diagnosis of HIV infection was established. A 37-yearold female patient was admitted with headache, fever, and weakness in the left arm and leg. Cranial MRI revealed contrastenhanced multiple parietal lesions compatible with toxoplasmosis. HIV infection was diagnosed by serologic tests. A 29-year-old male patient, who has been diagnosed with HIV infection 12 years ago but refused treatment, was admitted with weakness in his right arm and speech difficulty. Since cranial MRI revealed lesions compatible with toxoplasma encephalitis, the patient was initiated treatment for toxoplasmosis. In patients with focal cerebral lesions, HIV infection and the disorders facilitated by this infection should be kept in mind. (The Medical Bulletin of Haseki 2013; 51: 70-5)

Key Words: Toxoplasma encephalitis, HIV, hemiplegia

\section{Giriş}

Toxoplasma gondii zorunlu intrasellüler bir parazittir. Özellikle AIDS'li, organ nakli uygulanmış, kollajen doku hastalıkları ve retiküloendotelyel sistem malignitesi olan hastalarda fırsatçı patojen olarak karşımıza çıkmaktadır. T. gondii, uygun profilaksi altında olmayan HIV ile enfekte 
hastalarda fokal beyin lezyonlarının en sık nedenidir (1). CD4+ lenfosit sayısı $<100 / \mu l$ olan ve toksoplazma seropozitif olan hastaların yaklaşık \%30'unda toksoplazma reaktivasyonu görülebilir (2). Toksoplazma ensefalitinin (TE) en sık fokal nörolojik bulguları hemiparezi ve konuşma bozukluklarıdır. TE tanısı serolojik, klinik ve radyolojik olarak konulur. Radyolojik tanıda MR, BT'den daha duyarlıdır (3). Serumda IgM antikorları yeni enfeksiyonu gösterirken IgG titresindeki artış, toksoplazmozun reaktivasyonunun göstergesidir. Tedavide primetamin + sülfodiyazin kombinasyonu verilmektedir. Alternatif olarak primetamin + klindamisin kullanılabilir. Tedavi süresi yanıtlı hastalarda altı haftadır. Hastalık, klinik veya radyolojik olarak yaygın veya tedavinin altıncı haftasında tedaviye yanıt tam değilse tedavi süresi uzatılabilir. TE nedeniyle tedavi edilen tüm HIV ile enfekte hastalara sekonder profilaksi uygulanır $(4,5)$.

Bu çalışmada, kliniğimize fokal nörolojik bulgular ve ateş ile başvuran TE tanısının düşünülmesini takiben HIV enfeksiyonu saptanan iki TE olgusu ve daha önce HIV enfeksiyonu tanısı konulmuş, ancak kendi isteği ile tedavi başlanmamış kliniğimize TE ile başvuran bir olgu sunulmuş ve güncel literatür gözden geçirilmiştir.

\section{Olgu 1}

Yirmi sekiz yaşında erkek hasta, 20 gündür devam eden ateş, vücut sol yarısında güçsüzlük, halsizlik, iştahsızlık, gece terlemesi, öksürük, balgam çıkarma ve son iki hafta içinde altı kilo kaybı şikayetleri ile kliniğimize başvurdu.

Yirmi gün önce Tahran'da iş nedeniyle bulunduğu, şikayetlerinin o zaman başladığı ve çeşitli antibiyotikler kullandığı öğrenilen hastaya, en son başvurduğu doktor tarafından sanitasyonu bozuk bölgeye seyahat öyküsü ve üç haftadır süren ateş şikayeti nedeni ile tifo ön tanısı konularak siprofloksasin tedavisi başlanmış. Özel bir hastanede 15 gün süre ile ateş etiyolojisi araştırılan hasta, nedeni bilinmeyen ateş ön tanısı ile servisimize yatırıldı.

Özgeçmişi ve soygeçmişinde özellik olmayan hastanın başvuru sırasında yapılan fizik muayenesinde; aksiller ateş 38,6 oC, nabız: 100/dk, solunum sayısı 14/dk, kan basıncı: 95/65 mmHg olarak ölçüldü. Beslenmesinin 20 gündür kötü olduğu öğrenildi. Yardımsız yürüyemiyordu. Oral mukozada beyaz plaklar, solunum sistemi muayenesinde sol akciğer alt alanda solunum sesleri kabalaşmış, sağ akciğer alt alanda solunum seslerinde azalma mevcuttu. Nörolojik muayenede sol santral fasiyal paralizi, solda Babinski refleksi pozitifliği, sol kol ve sol bacakta kas gücü 3/5 olarak saptandı.

Laboratuvar incelemelerinde lökosit: 4200/mm³ (\%54 granülosit, \%6 atipik lenfositler, \%38 lenfosit), Ht \% 32.6,
Hb 11.2 g/dl, MCV: 90fL, trombosit: 203.000/mm33, CRP: $43 \mathrm{mg} / \mathrm{l}$ (N:0-5), eritrosit sedimentasyon hızı $60 \mathrm{~mm} /$ saat, ALT:48 U/L, AST: $65 \mathrm{U} / \mathrm{L}, \mathrm{LDH}: 715 \mathrm{U} / \mathrm{L}$ (220-450), albümin: $2.3 \mathrm{~g} / \mathrm{dl}$, ferritin $716 \mathrm{mg} / \mathrm{ml}$ (24-336) olarak saptandı. Dil-damak sürüntüsünde direkt incelemede maya hücreleri ve psödohifler görüldü. Kültüründe Candida albicans üredi. Uygulanan flukonazol (100 mg/gün; po) tedavisi sonucunda mukoziti geriledi.

P-A akciğer grafisinde sağ alt alanda interstisyel görünüm izlendi. Toraks bilgisayarlı tomografi (BT)'de, sağ akciğer alt lobda peribronşiyal infiltrasyon ve süperior segmentte buzlu cam görünümleri, sol akciğer üst lobda hava bronkogramı içeren konsolide alanlar, her iki akciğerde sentriasiner nodüller, sol akciğerde ince cidarlı kaviter lezyon görüldü. Kaviter lezyon, plevral sıvı varlığı nedeniyle tüberküloz (TB) ön tanısıyla dörtlü anti-TB tedavi (rifampisin 600 mg, INH 300 mg, etambutol 2 g, morfozinamid $3 \mathrm{~g}$ ) başlandı. Balgamın Ehrlich-ZiehlNeelsen (EZN) boyamasında aside dirençli basil görülmedi ve tüberküloz kültürü negatif kaldı. PPD negatif olarak saptandı. Ateşli dönemde 20 dakika arayla alınan iki hemokültürde üreme olmadı. İki ay sonra çekilen kontrol toraks $\mathrm{BT}^{\prime}$ de belirgin gerileme izlendi.

Nöroloji konsültasyonu sonrası çekilen kraniyal manyetik rezonans (MR) görüntülemede supratentorial alanda sağ talamusta kapsula interna, korona radiata düzeyine uzanan $2.5 \times 2 \mathrm{~cm}$, sağ temporal lob fuziform girusta tentorium komşuluğunda $1.5 \times 1 \mathrm{~cm}$, sol superior frontal girusta $1.5 \times 1 \mathrm{~cm}$ boyutlarında merkezleri nekroze, kontrast tutan 3 adet lezyon görüldü. MR'daki lezyonlar ön planda toksoplazma lezyonları olarak değerlendirdi. Toxoplasma IgM ve IgG pozitif olarak saptandı. Hastadan istenen anti-HIV antikorları pozitif olarak bulundu. Western blot ile HIV pozitifliği doğrulandı. HIV RNA viral yük 166.000 kopya/ml ve CD4 120/ul olarak saptandı. Hastanın ayrıntılı sorgulamasında 20 yıl Hollanda'da yaşamış olduğu ve erkeklerle seksüel ilişki (MSM) öyküsü olduğu öğrenildi. Hastaya lamivudin + zidovudin (2x1, po) ve lopinavir + ritonavir $(2 \times 2 \text {, po })^{\prime}$ den oluşan kombine antiretroviral tedavi başlandı.

Hastaya primetamin (2x50 mg po), klindamisin (4x600 mg IV) ve folinik asit $1 \times 15$ mg başlandı. Tedavinin 14. gününde idame dozuna geçildi. On dört gün sonra çekilen kraniyal MR'da lezyonlarda belirgin gerileme izlendi, karşılaştırılmalı raporda sağ talamustaki lezyonun, sol frontal lob medialinde, sağda temporoksipitalde medial kesimde yerleşimli lezyonların boyutlarında ve çevresinde ödemde azalma saptandı. Akciğer TB ön tanısıyla başlanan anti-TB tedavisi 6 aya tamamlandı. 
Hastanın ateşi geriledi, nörolojik bulguları düzeldi. Başvuru sırasında yardımla güçlükle yürüyebiliyorken, tedavi sonrasında yardımsız yürüyebilir hale geldi.

\section{Olgu 2}

Otuz yedi yaşında kadın hasta, baş ağrısı, ateş, sol kol ve bacakta güçsüzlük yakınmalarıyla kliniğimize başvurdu. Bu tarihten bir buçuk ay önce baş ağrısı şikayeti ile başka bir hastaneye başvuran hastaya çekilen kraniyal BT'de sağ frontobazalde $2 \times 3 \mathrm{~cm}$, çepersel kontrast tutan, çevresi ödemli kistik kitle görülmesi üzerine bir nöroşirürji uzmanına gönderilmiş. MR incelemesinde sağ frontal lob frontal sinüs komşuluğunda $16 \times 24 \times 20$ mm boyutlarında, çepersel kontrast tutan yer kaplayıc lezyon saptanmış. Lezyonun MR görünüm özellikleri ve yerleşimi göz önünde bulundurulduğunda ayırıcı tanıda geç serebrit ve intrakraniyal apse düşünülerek hastaya operasyon önerilmiş. Bir ay önce opere edilen hastanın patoloji sonucu; apseleşmeler gösteren hafif aktivasyonlu, kronik iltihaplı beyin dokusu olarak rapor edilmiş. Operasyon sonrasında sol elde ve bacakta güçsüzlük yakınmalarının ve baş ağrısının devam etmesi üzerine çekilen kraniyal MR'da her iki serebral hemisferde bilateral frontal, pariyetal, oksipital loblarda, her iki talamusta ve sol bazal gangliyonda en büyüğü $5.5 \mathrm{~cm}$ periferal minimal kontrast tutan, çevresi ödemli, çoğu subkortikal bileşke lokalizasyonunda yerleşimli çoklu parankimal nodüller görülmüş (Resim 1). Toraks BT'de sol akciğer alt lob ve sağ akciğer orta lobda fokal peribronşiyal nodüler infiltrasyonlar saptanıp, test terapötik antitüberküloz tedavi başlanmış. Yakınmaları gerilemeyen hasta kliniğimize sevk edildi ve ileri tetkik için yatırıldı.

Illk değerlendirmede yardımsız yürüyemiyordu. Aksiller ateş $38.9^{\circ} \mathrm{C}$ idi. Oral mukozada beyaz plaklar mevcuttu. Nörolojik muayenede sol hemiparezi, solda serebellar dismetri saptandı. Patolojik refleks saptanmadı. Göz dibi incelemesinde solda daha belirgin olmak üzere optik disk sınırları seçilemedi. Diğer sistem muayeneleri normaldi. Biyokimyasal parametreleri normal sınılarda, tam kan sayımında lökosit 2700/mm³ (\%72 PNL, \%14 çomak, \%10 lenfosit) olarak bulundu. Oral mukozadan ve dilden yapılan sürüntünün direkt incelemesinde mantar psödohifleri görüldü. Kültüründe Candida spp. üredi. Lokal antifungal tedavi ile lezyonlar geriledi. PPD anerjik olarak saptandı. Beyin omurilik sIVISI (BOS) incelemesinde lökosit:12/mm3 (\%80 parçalı), BOS'ta glukoz: $60 \mathrm{mg} / \mathrm{dl}$, protein: 30 mg/dl, eş zamanlı kan şekeri: $85 \mathrm{mg} / \mathrm{dl}$ olarak bulundu. BOS'un Gram boyamasında lökosit ve bakteri görülmedi.
EZN boyamasında aside dirençli basil görülmedi. BOS'ta tüberküloz polimeraz zincir reaksiyonu (PZR) ve VDRL negatif olarak saptandı. Kraniyal MR incelemede izlenen çepersel kontrast tutan, çoklu lezyonlar toksoplazmozu düşündürdüğünden istenen anti-HIV antikorları pozitif olarak bulundu ve Western blot ile doğrulandı. Toksoplasma IgM negatif, IgG pozitif olarak saptandı. Daha önce yapılan operasyon sırasında alınan beyin biyopsisine ait parafin bloklardan yapılan Toxoplasma gondii için PZR testi pozitif olarak sonuç verdi. HIV-RNA viral yük sayısı 174.670 kopya/ml ve CD4 50/ul olarak saptandı. Ayrıntılı göz muayenesinde toksoplazma koriyoretinit sekeli saptandı.

Hastaya 13 gün primetamin (1x100 mg, po) ve klindamisin (4x600 mg, IV) uygulandı. Tedavinin 12. gününde ateşi gerileyen hastanın, makülopapüler döküntüleri oluştu. Tedavi trimetoprim - sülfometaksazol (15 mg/kg/gün, IV) ile değiştirildi. Hastaya toksoplazmoz tedavisiyle eş zamanlı olarak lamivudin + zidovudin (2x1, po) ve lopinavir + ritonavir $(2 \times 2$, po)'den oluşan kombine antiretroviral tedavi ve Mycobacterium avium kompleksine yönelik azitromisin (1200 mg/hafta) profilaksisi başlandı.

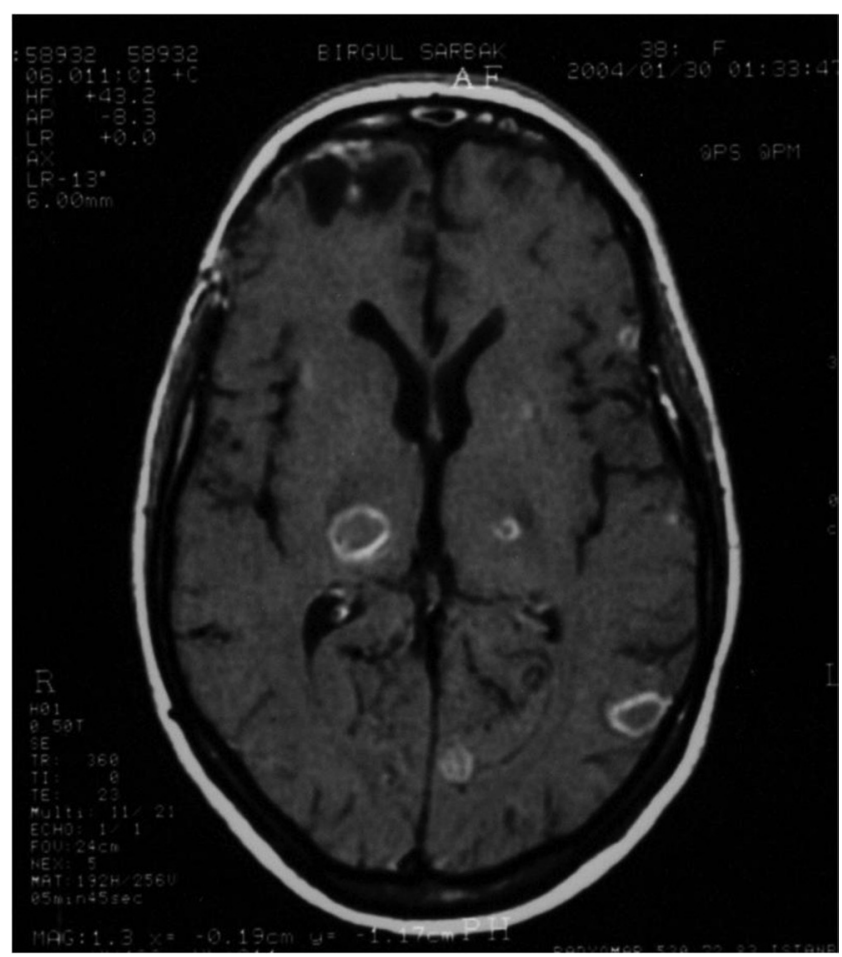

Resim 1. Her iki serebral hemisferde bilateral frontal, parietal, oksipital loblarda, her iki talamusta ve sol bazal ganglionda en büyüğü $5.5 \mathrm{~cm}$ periferal minimal kontrast tutan, çevresi ödemli, çoğu subkortikal bileşke lokalizasyonunda yerleşimli çoklu parankimal nodüller 


\section{Olgu 3}

Yirmi dokuz yaşında erkek hasta, sağ kolda güçsüzlük ve konuşmada güçlük şikayetleri ile kliniğimize başvurdu. On iki yıl önce yapılan tarama sırasında anti-HIV antikorları pozitif bulunmuş ve Western blot ile HIV pozitifliği doğrulanmış. Önce Almanya'da, daha sonra İstanbul'da bir hastanede takip edilen hasta tedaviyi reddetmiş. Bir hafta önce sağ kolda güçsüzlük ve konuşma güçlüğü gelişmesi üzerine, Acil Nöroloji Birimi'ne başvurmuş. Kraniyal MR incelemesi yapılan hastada ön planda toksoplazma ensefaliti düşündüren lezyonlar saptanması üzerine yatırıldı.

MSM öyküsü bulunan hastanın; esrar, kokain, ekstazi, sigara (2/3 paket/10 yıldır) kullanımı mevcuttu ancak intravenöz madde kullanımı yoktu.

Başvuru sırasında yapılan fizik muayenede; aksiller ateş $36.9{ }^{\circ} \mathrm{C}$, nabız 76/dk, kan basıncı: 95/70 mmHg idi. Oral mukozada beyaz plaklar görüldü. Nörolojik muayenede; sağ santral fasiyal parezi, motor disfazi ve sağ üst ekstremite distalinde belirgin parezi saptandı. Göz dibi incelemesinde bir patolojiye rastlanmadı. Diğer sistem muayeneleri normal olarak bulundu.

Tam kan sayımında lökosit 7200/mm³ (\%50 PNL, \%30 lenfosit, \%17 monosit), $\mathrm{Hb}: 15 \mathrm{~g} / \mathrm{dl}, \mathrm{Ht}$ : \%43.3 olarak bulundu. CRP: $7.59 \mathrm{mg} / \mathrm{L}(\mathrm{N}<5)$ eritrosit sedimentasyon hızı $34 \mathrm{~mm} /$ saat, biyokimyasal parametreleri normal olarak saptandı. Oral mukozadan yapılan sürüntünün direkt incelemesinde mantar psödohifleri görüldü. Kültüründe Candida spp. üredi. Flukonazol (100 mg/gün; po) başlanan hastanın, tedavi sonucunda mukoziti geriledi. PPD anerjik olarak saptandı. Tekrarlanan Anti-HIV antikorları pozitif olarak bulundu. HIV serolojisi Western blot ile doğrulandı.

Kraniyal MR incelemede sol frontal lob süperiorunda yerleşik, düzensiz çepersel kontrast tutulumu gösteren ve belirgin çevresel ödemin eşlik ettiği çoklu lezyonlar toksoplazmoz olarak değerlendirildi. Toxoplasma IgM ve IgG negatif olarak saptandı. HIV RNA viral yük 48.364 kopya/ml ve CD4 72/ul olarak saptandı.

Hastaya primetamin (1×75 mg, po), klindamisin (4x600 mg, po), folinik asit (1×25 mg, po) başlandı. Hastaya lamivudin + zidovudin $(2 \times 1$, po) ve lopinavir + ritonavir $(2 \times 2$, po)'den oluşan kombine antiretroviral tedavi başlandı. Mycobacterium avium kompleksi için klaritromisin (2x500mg, po) profilaksisi başlandı. Tedavinin 15. gününde çekilen kraniyal $M R$ incelemede eski lezyonların boyutlarında ve çevresel ödem alanlarında belirgin regresyon izlendi. Nörolojik bulguları düzeldi.

\section{Tartışma}

Toksoplazmoz, tüm dünyada yaygın parazitik bir hastalıktır ve primer olguların çoğu asemptomatiktir. AIDS'li hastalarda santral sinir sisteminde yer kaplayıcı lezyon varlığında ilk planda dışlanması gereken hastalık serebral toksoplazmoz olup, hücresel bağışıklığın ilerleyici kaybına bağlı olarak latent enfeksiyonun reaktivasyonu sonucu ortaya çıkar. Normal konakta semptomatik serebrospinal toksoplazmoz nadiren görülür $(6,7)$.

TE'nin en sık klinik bulguları baş ağrısı, konfüzyon, ateş ve halsizliktir. TE'li hastaların \%50-60'ı fokal nörolojik bulgularla başvurur; hemiparezi ve konuşma bozuklukları en sık görülen fokal nörolojik bulgulardır. Nadiren diffüz ensefalit olarak ortaya çıkabilir (6).

Fokal nörolojik bulgularla başvuran TE'li hastalarda radyolojik görüntüleme şarttır. Tanı için $\mathrm{MR}, \mathrm{BT}^{\prime}$ den daha duyarlıdır. Tipik olarak çoklu çepersel kontrast tutan, etrafında ödem olan ve kitle etkisi olan lezyonlar görülür (2).

CD4 T lenfosit hücresi $<100 / \mu l$ olan hastada serumda antitoksoplazma IgG antikor artışının varlığı, klinik ve radyolojik bulguların TE ile uyumlu olması, ampirik toksoplazma tedavisine klinik ve radyolojik yanıt alınması tanıyı destekleyici bulgulardır. Kesin tanı tutulan dokuda, kanda veya diğer sıvılarda parazitin taşizoid formunun saptanmasıyla konur (2).

Her iki hastamızdaki fokal nörolojik bulgular ve MR incelemedeki çoklu lezyonların varlığı, serumda IgG antikorlarının pozitifliği TE tanımızı destekleyen bulgulardır. Üçüncü olguda antitoksoplazma lgG negatif bulunsa da, hastanın altta yatan hastalığı, karakteristik görüntüleme bulguları, tedaviye klinik ve radyolojik yanıt alınması nedeniyle hastada toksoplazma ensefaliti düşünüldü. HIV enfeksiyonlu hastalarda seronegatif toksoplazmoz olguların \%0-3'ünü oluşturur. Ancak bir çalışmada seronegatiflik oranı \%22 olarak bildirilmiştir (8). İlk hastamızda tedavinin 2. ve 8. haftalarında, üçüncü hastamızda tedavinin 2 . haftasında çekilen MR görüntülemelerde belirgin regresyon gözlenmesi tanıyı desteklemiştir.

AIDS'li hastada merkezi sinir sistemi tutulumu varlığında ilk olarak düşünülecek hastalıklar TE, primer santral sinir sistemi lenfoması, kriptokok menenjiti, progresif multifokal lökoensefalopati ve sitomagalovirus (CMV) enfeksiyonudur (9).

Primer merkezi sinir sistemi lenfoması, HIV enfeksiyonlu hastalarda topluma göre 1000-3900 kat daha sık görülmektedir (10). Merkezi sinir sisteminde yer kaplayıcı lezyon olarak toksoplazmadan sonra ikinci sıradadır. Bu tümörlerin çoğunluğu supratentoriyal yerleşimlidir. 
Klinik olarak TE ile benzer bulgular göstermektedir. Radyolojik olarak MR ile görüntülenebilen tek ya da çoklu lezyonlar olabilir. Soliter lezyonların varlığı, lezyonların ventrikül komşuluğu, subependimal yayılma, kontrast tutan bu lezyonların halka şeklinden çok homojen olması toksoplazmozdan ayırımda önemli özelliklerdir $(11,12)$.

Kriptokok menenjiti; ense sertliği, meningismus, fotofobi gibi menenjit belirti ve bulgularıyla başvurur. Hastaların \%10'unda fokal nörolojik belirti ve bulgular görülebilir. Hastaların \%50'sinde intrakraniyal basınç artışı, hidrosefali ve serebral ödem görülebilir $(13,14)$. Görüntüleme, obstrüktif hidrosefali tanısını kesinleştirmek için gereklidir. Kriptokok menenjitinde çoklu beyin lezyonları görülmediğinden, bizim hastalarımızda bu tanı düşünülmemiştir.

Progresif multifokal lökoensefalopati, JC virüsüne bağlı sıklıkla ölümcül seyreden demiyelinizan bir hastalıktır. Nadir görülür. Tipik olarak MR incelemede serebral hemisferde beyaz maddenin tutulduğu çoklu odakları olan sinyal artışları görülür. Kitle etkisi yoktur ve sinyal tutmaz (15).

CMV enfeksiyonu, AIDS'li hastalarda periferik ve santral sinir sistemini tutar. Ensefalit, poliradikülit, poliradikülomiyelit ve periferal myopati görülür. Klinik olarak ayırt edici bir özelliği yoktur. CMV ensefaliti, genelde CD4 T lenfosit sayısı çok düşük olan (<50 hücre/ $\mu l)$ hastalarda görülür. MR incelemede sinyal artışı görülebilir. Klinik ve radyolojik bulgular ve BOS incelemesi tanıtıcı değildir.

Çepersel kontrast tutulum gösteren fokal beyin lezyonu/ları olan HIV enfeksiyonlu hastalarda tedavide birinci basamak yaklaşım ampirik toksoplazmoz tedavisidir. Klinik veya radyolojik olarak (tedavinin 2-3. haftasında görüntüleme) yanıt olmayan hastalarda tanıya yönelik biyposi yapılır (2).

AIDS'li hastalarda toksoplazmoz tedavisi primer tedavi, idame tedavi ve primer profilaksiyi içerir. Bu hastaların \%75-80'inden fazlasında toksoplazmoz tedavisi başarılıdır. Tedavide ilk seçenek, primetamin ve sulfodiyazin kombinasyonudur. Primetaminin hematopoetik toksititesini engellemek için tedaviye folinik asit eklenir. Tedavide alternatif olarak primetamin- klindamisin kombinasyonu veya trimetoprim-sülfametoksazol kullanılabilir. İndüksiyon tedavisi 6 hafta olarak uygulanır. Sözü edilen ilaçlar sadece intraselüler ve serbest taşizoidlere etkili olup doku kistlerine karşı etkili değildir. Bu nedenle serebral toksoplazma tedavisinden sonra aynı ajanlar daha düşük dozda kullanılarak supresyon tedavisi yapılmalıdır $(2,6)$. Birinci hastamızda 6 hafta boyunca primetamin-klindamisin kombinasyon tedavisi verilmiş, tedavinin ikinci haftasında ve sekizinci haftalarda çekilen $M R$ görüntülemelerde belirgin gerileme izlenmiştir. Baskılayıcı tedavi olarak primetamin-klindamisin daha düşük dozlarda verilmiştir. İkinci olgumuzda primetamin tedavisinin 13. gününde reaksiyon gelişmesi üzerine trimetoprim-sülfometaksazol tedavisine geçilmiştir. Tedavinin 2. haftasında klinik düzelme gözlenmiştir.

Ülkemizde HIV enfeksiyonu ender görülen ancak son dönemde artış gösteren bir hastalıktır. Saptandığında mutlaka HIV enfeksiyonunun araştırılması gereken bazı hastalıklar mevcuttur. Serebral toksoplazmoz da saptandığında HIV enfeksiyonunun araştırılması gerektiği hastalıklar arasında yer almaktadır (16).

Sonuç olarak, HIV enfeksiyonu ülkemizde ender görülen bir hastalık olmasına rağmen, son yıllarda hastalığın prevalansında artış gözlenmektedir. Fokal beyin lezyonları saptanan hastalarda, HIV enfeksiyonu ve onun kolaylaştırdığı patolojiler akılda tutulmalıdır.

\section{Kaynaklar}

1. San-Andrés FJ, Rubio R, Castilla J, et al. Incidence of acquired immunodeficiency syndrome-associated opportunistic diseases and the effect of treatment on a cohort of 1115 patients infected with human immunodeficiency virus, 1989-1997. Clin Infect Dis 2003;36:1177-85.

2. Heller HM. Toxoplasmosis in HIV infected patients. Available from: URL: http://www.uptodate.com/contents/toxoplasmosisin-hiv-infected-patients. Accessed May 20, 2012.

3. Levy RM, Mills CM, Posin JP, Moore SG, Rosenblum ML, Bredesen DE. The efficacy and clinical impact of brain imaging in neurologically symptomatic AIDS patients: a prospective CT/MRI study. J Acquir Immune Defic Syndr 1990;3:461-71.

4. Mortality and Morbidity Weekly Report (MMWR). Guidelines for Prevention and Treatment of opportunistic Infections in HIV-Infected Adults and Adolescents: Available from: URL:http://www.cdc.gov/mmwr. Accessed May 12, 2012.

5. Montoya JG, Remington JS. Toxoplasma gondii. In: Mandell $\mathrm{GL}$, Bennet JE, Dolin R, editors. Principles and Practice Infections Diseases. 5th ed. Philadelphia: Churchill- Livingstone Inc; 2000. p. 2558-88.

6. Murray H. Toxoplasmosis. In: Dolin R, Masur H, Saag M, editors. AIDS Therapy, New York: Churchil Livingstone; 1999. p. 307-27.

7. Saltoğlu N, Dündar iH, Aksu HSZ, et al. Serebral toksoplazmoz: Bir olgu sunusu. İnfeksiyon Derg 1996;10:311-8.

8. Suh SS, Sepkowitz KA. Opportunistic infections in HIV disease. Betts RF, Chapman SW, Penn RL, editors. Reese and Betts' a practical approach to infectious diseases. 5th ed. Philadelphia: Lippincot Williams \& Wilkins; 2003. p. 691.

9. Mamidi A, DeSimone JA, Pomerantz RJ. Central nervous system infections in individuals with HIV-1 infection. J Neurovirol 2002:8:158-67.

10. Raez LE, Patel P, Feun L, Restrepo A, Raub WA Jr, Cassileth PA. Natural history and prognostic factors for survival in patients with acquired immune deficiency syndrome (AIDS)-related primary central nervous system lymphoma (PCNSL). Crit Rev Oncog 1998;9:199-208. 
Demirel ve ark. Hemipleji ile Başvuran HIV Enfeksiyonu

11. Ammassari A, Scoppettuolo G, Murri R, et al. Changing disease patterns in focal brain lesion-causing disorders in AIDS. J Acquir Immune Defic Syndr Hum Retrovirol 1998;18:365-71.

12. Fine HA, Mayer RJ. Primary central nervous system lymphoma. Ann Intern Med 1993;119:1093-104.

13. Saag MS, Graybill RJ, Larsen RA, et al. Practice guidelines for the management of cryptococcal disease. Infectious Diseases Society of America. Clin Infect Dis 2000;30:710-18.
14. Wright D, Schneider A, Berger JR. Central nervous system opportunistic infections. Neuroimaging Clin N Am 1997:7:513-25.

15. Berger JR, Pall L, Lanska D, Whiteman M. Progressive multifocal leukoencephalopathy in patients with HIV infection. J Neuro Virol 1998;4:59-68.

16. Kaplan JE, Hanson D, Dworkin MS, et al. Epidemiology of human immunodeficiency virus-associated opportunistic infections in the United States in the era of highly active antiretroviral therapy. Clin Infect Dis 2000;30(Suppl 1):5-14. 